\title{
Етиологично доказан случай на туберкулозен отит
}

\author{
Е. Бачийска ${ }^{1}$ Кр. Бозов², Е. Бозова², Ю. Атанасова, \\ А. Иванова ${ }^{1}$, Д. Мерджанов ${ }^{1}$ \\ ${ }^{1}$ НЦЗПБ - София \\ МБАЛ - Шумен АД, гр. Шумен
}

\begin{abstract}
Резюме
Представяме случай на туберкулозен отит при млада жена, открит след добра колаборация между специалист по оторино-ларингология и микробиолог, търсещи активно специфична етиологична нокса, след като в продължение на две години пациентката не е получила адекватна диагноза и лечение. При поставянето на етиологичната диагноза и потвърждението ѝ са използвани конвенционални класически и модерни микробиологични методи: чрез напълно автоматизирани системи и съвременни генетични тестове. След включване на подходяща противотуберкулозна терапия пациентката се повлиява и се възстановява.
\end{abstract}

лучаят е наблюдаван и открит в отделение по УНГ и Микробиологична лаборатория, „МБАЛ - Шумен“ АД, гр. Шумен и потвърден в НРЛ по туберкулоза, Национален център по заразни и паразитни болести, гр. София.

Отнася се за 36-годишна жена, имала оплаквания от 2004 г. По анамнестични данни след остра инфекция на ГДП жената е получила свистене в дясното ухо, без болка, за което не е търсила лекарска помощ. При последващо заболяване на ГДП получава болка в дясното ухо, съпроводена с гноевидна секреция. При преглед от УНГ специалист е установена перфорация на дясната тъпанчева мембрана. Проведено е антибиотично лечение - Gentamycin и ушни капки. Многократните обостряния до април 2006 год. са лекувани от различни УНГ специалисти с временно подобрение.

На 20.04.2006 год. след проведено едноседмично консервативно лечение по повод болка и гноетечение от дясното ухо, съпьтствани от световъртеж, жената е насочена и приета в УНГ отделение на „МБАЛ Шумен“ АД с диагноза Otitis media suppurativa chronica exacerbata dextra. Epitympanitis dextra.

Минали заболявания: не съобщава, освен отитите от 2004 год.

От фамилната анамнеза (получена от пациентката едва след доказване на туберкулозата): Съпруг заболял на 27 год. от белодробна туберкулоза с каверни през 1992 год. Лекуван в Областния диспансер за пневмофтизиатрични заболявания със стационар гр. Шумен с първоначален 6-месечен курс и последващи пролежавания. Кръвохракът му продължава и през 1993 год., когато пациентьт слага край на живота си. Съпругата му и двете им деца са изследвани за тубер- 
кулоза като контактни и са провели стандартната профилактика към ОДПФЗС - Шумен.

Рискови фактори: От 2004 год. пациентката работи в птицекомбинат на влага, студ и течение, с което свързва началото и обострянията на заболяванеTо.

От обективното състояние: жена на видима възраст около 35-36 год., отговаряща на действителната, в запазено общо състояние, ориентирана за време и място. Афебрилна през цялото пролежаване.

При отоскопия се наблюдава мацерирана, свличаща се кожа на външен слухов проход. Тъпанчевата мембрана е набъбнала, мацерирана, без очертани анатомични подробности. През перфорация с неравни ръбове в задно-горни квадранти изтича с пулсации белезникав, на моменти кръвенист гноевиден секрет, без характерна миризма. При активна аспирация се наблюдават единични холестеатомни люспи от перфорацията. Наличие на по-малки от просено зърно, меки, кървящи при допир гранулации по ръба на перфорацията и на места по каналната стена.

От направените изследвания: Кръвна картина: в референтни стойности, ДКК: Ly 42,5\%; Mon 6,5\%; Gra 51,0. При рентгенография на двата мастоидни процесуса по Шулер се наблюдават воалирани клетки с намалена прозрачност в дясно периантрално. От аудиометрията: звукопроводно намаление на слуха за дясното ухо в граници на тежко чуване. Направено е микробиологично изследване на ушен секрет за неспецифична микробна флора с резултат: „Не се изолира патогенна флора“.

Включената терапия е: Ceftriaxon 2 x 1g, Mannitol, вливания. На 28.04.2004 год. е проведено оперативно лечение: Meatoaticoantrotomia. Установена е деструкция на част от периантралните клетки с гранулации в атика и тъпанчевата кухина. Почистени са гранулациите и клетките до здраво и е направена пластика.

При следоперативното наблюдение: оперативният разрез първоначално зараства добре, но кухината продължава да секретира. След около месец се отваря оперативният разрез, като кожата на външния слухов проход е силно болезнена и секрецията се увеличава. От направените 4 последователни микробиологични изследвания за неспецифична флора на ушен секрет се установява еднократно Candida albicans (умерено количество, 03.08.2006 г). Проведено е съответно лечение, но секрецията намалява за кратко.

При следващо пролежаване в УНГ-отделение (01.12.2006 г.) по повод не зарастване на раната, изконсумиране на част от кожата на външния слухов проход и световъртеж се извършват поредни микробиологични изследвания на ушен секрет в лабораторията на МБАЛ Шумен, включително и за туберкулоза. Резултатьт от изследването за неспецифична флора е „Без растеж“. Микроскопското изследване на препарат, оцветен по Ziehl-Neelsen, е положително: наличие на киселиноустойчиви бактерии в количество (2+), т.е. от 1 до 10 КУБ на всяко зрително поле. Културелното изследване също е положително в количество $(2+)$, т.е. растеж на микобактерии над 100 колонии. Използвана е твърда хранителна среда на Löwenstei-Jensen, която позитивира на 20-я ден (лаб. № 1342/01.12.2006 г.). Тест за лекарствена чувствителност към първи ред противотуберкулозни препарати е направен на 22.12.2006 г. с автоматизирана система ВасТ/ ALERT 3D 60, BioMerieux., отчетен на 01.01.2007 г. като чувствителен.

От направените отоневрологични изследвания: електронистагмография с данни за периферен отоневрологичен синдром.

При получаване на положителния резултат за киселиноустойчиви бактерии от директната микроскопия е направена рентгенография на бял дроб, показваща засенчване в дясно върхово поле, свързано с хилуса. Не може да се прецени активността на процеса.

След консултация с пневмо-фтизиатър пациентката е насочена за уточняване и лечение към ОДПФЗС - Шумен, с диагноза Otitis media tuberculosa.

Направени са микробиологични изследвания на три последователни храчки за туберкулоза, с посявки на твърда хранителна среда на Löwenstei-Jensen и течна MP, с автоматизираната система ВасТ/ ALERT 3D 60, BioMerieux. Получените резултати са: първата храчка с лаб. № 1362/12.12.2006 г. е отрицателна на микроскопското изследване по Ziehl-Neelsen и полжителна на посявката на течната хранителна среда на 17-я ден от началото на култивирането. На твърдата хранителна среда е отчетен положителен резултат с оскъден растеж от 5 колонии на шестата седмица. Останалите две последователни храчки с лабораторни номера съответно № 1362/13.12.06 г. и № 1374/14.12.06 г./ са били отрицателни за микобактерии микроскопски и културелно.

При контролен преглед в УНГ отделение на МБАЛ Шумен на третия месец от противотуберкулозното лечение се установява напълно зараснала оперативна рана, възстановена целостта на кожата на външен слухов проход и тъпанчевата мембрана. Липсва секреция.

Изолираният щам от ушен секрет с лаб. № 1342 е изпратен в НРЛ по туберкулоза, НЦЗПБ за 
потвърждение на 15.02.2007 г. Тук щамът е подробно проучен. Направени са изследвания с течна хранителна среда MGIT с напьлно автоматизираната система Bactec MGIT 960 System, като на 19.02.2007 г. е пуснат тест за идентификация с паранитробензоена киселина и тест за лекарствена чувствителност към първи ред противотуберкулозни препарати.

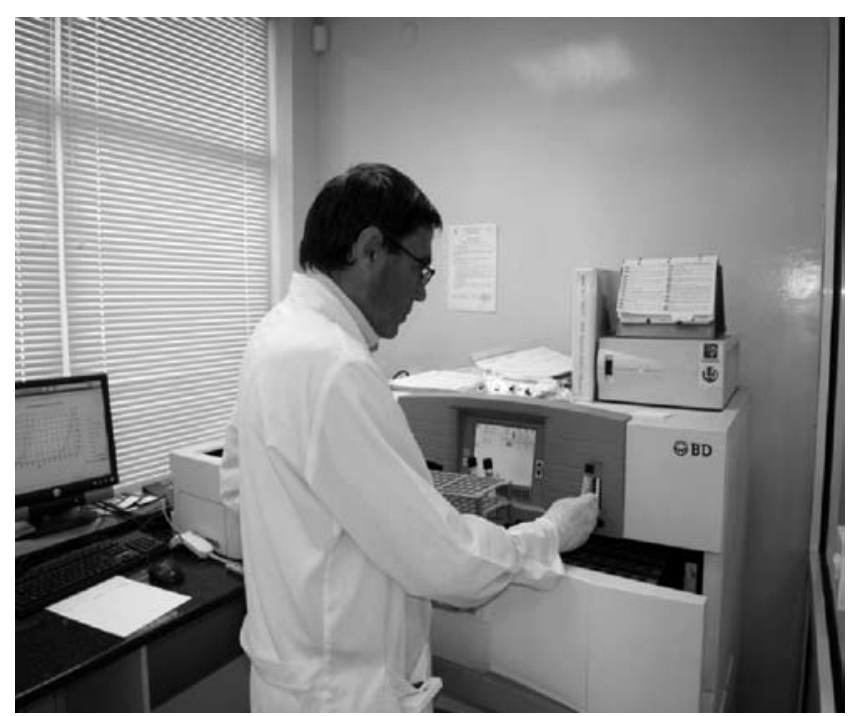

Фиг. 1. Автоматизирана система Bactec MGIT 960, НРЛ, НЦЗПБ

Резултатите са отчетени автоматично на 27.02. 2007 г., т.е. на осмия ден от начало на стартиране на пробата, като чувствителен на Streptomycin, Isoniazid, Rifampin и Ethambutol.

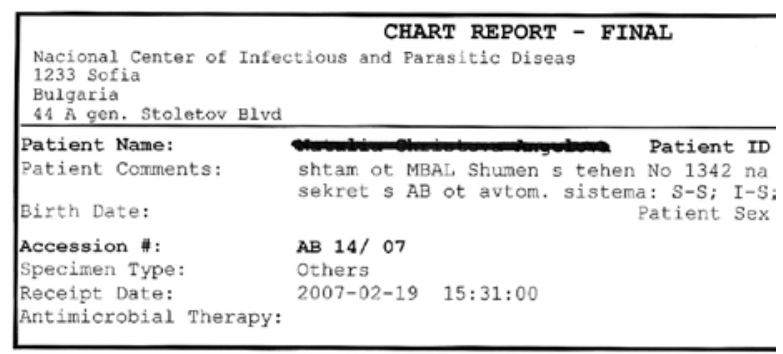

\begin{tabular}{|c|c|}
\hline Test Name & Isolate \# Result \\
\hline MGIT 9605 Tube Carrier Set & Completed Removed \\
\hline Organism Name & Comments \\
\hline
\end{tabular}

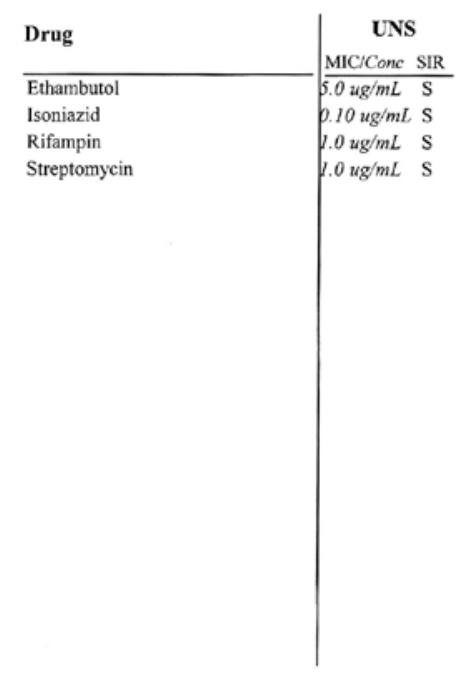

Фиг. 2. Автоматична интерпретация на резултата от антибиограмата

AST Tube Carrier Set Plot (Up to 8 tubes)

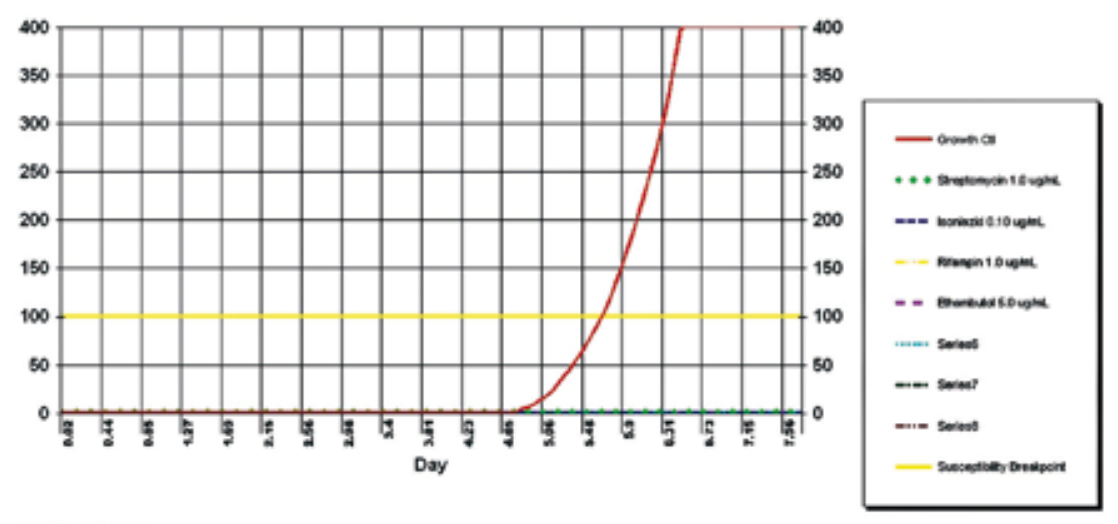

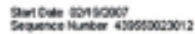

Фиг. 3. Растежна крива при проследяване на чувствителността към първи ред противотуберкулозни препатрати 
Резултатът от пара-нитро бензоената киселина е отрицателен, т.е. касае се за Mycobacterium tuberculosis complex, като той е потвърден и чрез генетичен тест за видова идентификация Geno Type, HAIN, CM.

Генетични тестове s DNA S TRIP-Technology

І етап - Изолиране на ДНК

I етап - Амплифициране на спейсърния регион между 16 S-23S P PHK гени с помощта на специфични праймери

II етап - Обратна хибридизация

IV етап - Визуализаране и отчитане на резултата
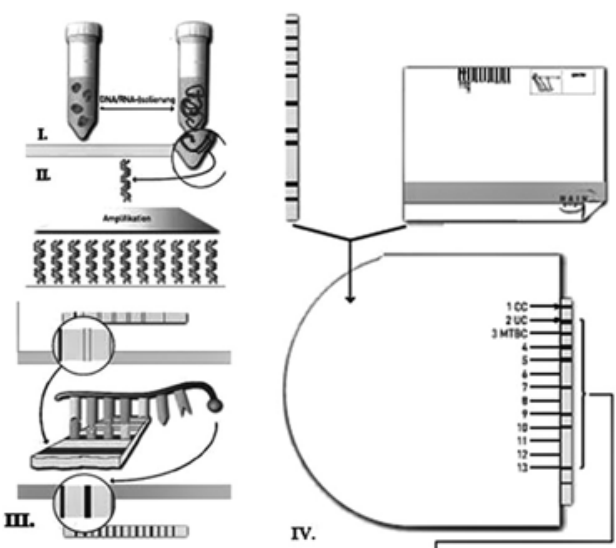

Фиг. 4. Схема на генетичен тест, Geno Type, HAIN, CM

\section{Заключение}

След края на 80-те години на миналия век заболеваемостта в световен и регионален мащаб започна бавно да нараства. На практика няма орган, който да не може да бъде поразен, но в последните години не се мисли за това заболяване, смятайки го за заболяване от отминала епоха. Представеният случай в „МБАЛ-Шумен“ доказва присъствието на тази патология в наши дни и необходимостта от активно търсене на етиологична нокса при протичащи с нетипична клинична картина заболявания. При добра колаборация между клиницисти и микробиолози днес модерната микробиологична техника дава възможност за поставянето на бърза и надеждна етиологична диагностика. 